\title{
Protecting the Third Party-Owned Evidence in Corruption Cases: Analysis of Case at the Prosecution Stage
}

\author{
Lukman Hakim ${ }^{1 *}$, Muhadar ${ }^{2}$, M. Syukri Akub ${ }^{2}$, Mustafa Bola ${ }^{2}$ \\ ${ }^{1}$ Attorney General of the Republic of Indonesia, Indonesia \\ ${ }^{2}$ Faculty of Law, Hasanuddin University, South Sulawesi, Indonesia \\ ${ }^{*}$ Corresponding author
}

\begin{abstract}
The research aims to analyze and find out the legal protection of third party-owned evidence in corruption cases at the prosecution stage. This research is descriptive with normative-juridical type. The approaches used were statutory, conceptual, and case approaches by using deductive and inductive reasoning. The results show that the presence of a third party in the prosecution trial can cut time in providing legal certainty regarding the legal status of the object claimed by the third party which is the object of confiscation. This provision eliminates pretrial attempts and challenges (derden verstek) against the confiscation of objects of confiscation. The legal status of the object of confiscation which is claimed by a third party is completed in one trial, the prosecution trial; the second is efficiency of case handling for proving the validity of the object of confiscation of evidence belonging to a third party occurs in just one prosecution hearing, there is no pretrial effort and resistance to objections after the decision. The third is avoid disparity in decisions. Separating the evidentiary process in the corruption court with the pretrial and civil proceedings (resistance from third parties or defendants) can result in disparities in decisions that confuse justice seekers. The fourth is avoid the practice of corruption. The process of proving the object of confiscation in one agenda of the prosecution session minimizes the chance of corruption (bribery) because the evidence trial focuses on the prosecution trial only.
\end{abstract}

Keywords: Attorney; Corruption; Third Party-Owned Evidence; Prosecutor

DOI: $10.7176 / \mathrm{JLPG} / 102-10$

Publication date:October $31^{\text {st }} 2020$

\section{Introduction}

Much of the academic literature that aims to explain the occurrence of corruption is based on rational-choice assumptions - that is, individuals are assumed to be rational beings who act to maximise their self-interest. ${ }^{12}$ In turn, these strategic decisions shape the organisation of corruption. In this corruption regime, the particularistic allocation of public resources does not primarily occur on the basis of bribes but rather on the basis of personal connections, mainly in the form of patron-client networks. More specifically, informal networks - in competition with each other - extract public resources out of the state.

Recently, corruption has become a very serious legal problem. As a result of corruption as occurred so far, besides causes losses to the State finances or the economy, it also hinders the growth and sustainability of national development which demands high efficiency. ${ }^{3}$ Corruption has been seen as a vicious cycle that revolves all factors and actors, both in the legislative, executive and judicial institutions. This phenomenon should receive attention from all parties because it is not only detrimental to the finances and/or economy of the country but can also damage the image of the nation in the international world. ${ }^{4}$

In the economic sector, every criminal act including corruption, there are at least 3 (three) components that are always contained in it, namely the perpetrator, the criminal act committed and the proceeds of crime. For perpetrator, assets of a criminal act are the "live blood of crime" or the backbone of crime, which means that the proceeds of crime are likened to "blood flow" that supports the crime itself, and is also the weakest point in the crime chain. ${ }^{5}$ Based on this understanding, law enforcement should begin to be directed towards the concept of Follow the Money replacing the concept of Follow the Suspect by examining the flow of funds from downstream

1 Njoto-Feillard, G., \& Azali, K. (2016). Is a New Entrepreneurial Generation Emerging in Indonesia?. SEAS Yusof Ishak Institute. http://hdl.handle.net/11540/9160.

2 Hellmann, O. L. L. I. (2015). "The Institutionalisation of Corruption: The Neglected Role of Power." In th PSA Annual International Conference Sheffield, vol. 30. 12-43.

3 Preamble letter (b) the Corruption Laws No 31 of 1999

4 Semma, M. (2008). Negara dan Korupsi; Pemikiran Mochtar Lubis Atas Negara, Manusia Indonesia dan Perilaku Politik, Jakarta: Yayasan Obor Indonesia, p. 15.

5 Hussein, Y. (2008). Negeri Sang Pencuci Uang, Jakarta, Pustaka Juanda Tigalima, p.67 
to upstream to confiscate/seize assets that are suspected of being the result of the crime. ${ }^{1}$

Without an independent attorney, it is impossible for an independent judicial authority to be realized. In other words, an independent attorney also contributes to the realization of the legal supremacy which has a strong influence on the realization of democratic statehood. ${ }^{2}$ By the good legal supremacy, it is expected to be able to support the creation of a democratic political process so that it can produce professional leaders with integrity. In addition, a good legal supremacy is ultimately expected to bring about justice, legal certainty, and benefits for society.

In order to prevent and eradicate corruption crime in an effective and aspirational manner with public demands, it is important to considers the law enforcement officials and their laws and regulations. The success of law enforcement on corruption cannot be separated from 5 (five) main officers namely police, prosecutors, judges, lawyers, and correctional institutions. ${ }^{3}$ During this, there are 3 (three) elements of the legal system, including legal structure, legal substance, and legal culture. If viewed from these elements, then one of the most important elements in the occurrence of law enforcement violations, as result of no professionalism among law enforcers. ${ }^{4}$ Another notion that the success of law enforcement depends on the professionalism of the apparatus.

Items that can be confiscated are items of a suspect or defendant, or other parties, which in whole or in part are alleged to have been obtained from a criminal act. In a corruption case, the Police, the Attorney General or the Corruption Eradication Commission may take action to confiscate any objects or items which is strongly suspected that the objects such as land or other immovable and immovable are the result of corruption. For example, a perpetrator of a criminal act of corruption buys a piece of land as a result of corruption. The land may be in the name of a third party. Based on this allegation, the Police, the Attorney, or the Corruption Eradication Commission confiscated the land. This was done because the investigators already knew the origin or history of the land controlled by the third party. Investigators hold strong information and data if the land on behalf of a third party as result of corruption. One of the modes is by making a fictitious sale and purchase between the perpetrator of corruption and the third party, as if the land belongs to a third party. By this data, the investigator has the authority to confiscate the land for the sake of proof during the prosecution stage.

After the investigator confiscates objects controlled by the defendant or owned by a third party that were obtained illegally as evidence at trial, and so on until the trial verdict that the confiscated evidence is confiscated for the State (verbeurd verklaard), including evidence from third parties. Certainly, the third party reacted and responded to the decision. The response is likely not accepting or objecting to the decision. It is not uncommon for a third party not to accept a verdict, because he feels that his rights have been confiscated for the State, while he has strong evidence of objects in the form of a piece of land possessed. The third party feels their rights are being violated.

Also, it is emphasized that it is not permissible to confiscate the property of a guilty person who is not the result of a violation or crime, which is stated in article 19 of the Corruption Laws that "no violation or crime of any kind is punishable by confiscation of all property belonging to the guilty." What is meant by all the assets belonging to the guilty is the price that does not originate from an offense or crime. ${ }^{5}$ The right to material or object is part of universal human rights that must be protected, respected, defended, and should not be neglected, reduced or taken away by anyone. ${ }^{6}$

However, at a practical level, this legal protection has not been considered maximized, considering that a third party with good faith is not drawn as a related party in the prosecution trial. Even if they are presented, they must be submitted by the prosecutor or defendant. If not, then the third party must wait for a verdict, or file a foreclosure pretrial, whose trial is separate from the prosecution for corruption cases. The prosecution hearing only involved the prosecutor and the defendant who was accompanied by their legal counsel. Whereas the third party has a legal interest to explain and prove the rights regarding the origin of the object or asset which is the object of the confiscation. This situation is one of the deficiencies in criminal procedural law, so that this problem is the main topic of this research (research gap).

1 Hussein, Y. (2007). Bunga Rampai Anti Pencucian Uang, Bandung: Books Terrace \& Library, p.250

2 Alhumami, K., Arie, M., Musakkir, Sampurno, S.S. (2020). Attorney's Independence in Implementing Law Enforcement Duties: Challenges and Development, Journal of Law, Policy, and Globalization, Vol. 95, 106-112

3 Modul Tindak Pidana Korupsi, Pendidikan Dan Pelatihan Pembentukan Jaksa 2019, Published by Tim Penyusun Modul Badan Diklat Kejaksaan RI, Jakarta, 2019, p.iii.

4 Lamintang, (1984). KUHAP dengan Pembahasan secara Yuridis menuruf Jurisprudensi dan ilmu Pengetahuan Hukum Pidana, Bandung: Sinar Baru, p. 14.

5 Elucidation of Article 19 Act No. 39 of 1999 concerning the Human Right

6 Preamble of Act No 39 of 1999 concerning the Human Right, letter (b) 


\section{Method}

This research is a normative-juridical research. ${ }^{1}$ The approach used is statute, conceptual, and case approaches. It was conducted at the Corruption Eradication Commission and the Junior Attorney General for Special Crimes at the Attorney General Office of the Republic of Indonesia in Jakarta. It was qualitative research by relying on library research with the approach of primary and secondary legal materials. ${ }^{2}$

\section{Linkages of Third Parties in Corruption}

Not infrequently the judge' decision mention that the evidence confiscated from the control of a third party is proven not to be the result of corruption or not related to the corruption, and it is decided to return it to the rightful party (third party in good faith). The confiscated evidence is legally obtained through civil relations such as sale and purchase, contracts and other forms of engagement. So that the third party feels that it is materially disadvantaged if it is confiscated for the State because it has incurred costs to have the evidence.

Non-juridical considerations of the judge are more subjective in relation to matters concerning the suspect's life. Like the economic condition, the attitude in the trial, whether the defendant has been convicted or not, includes the element of "judge' conviction" on the criminal act the defendant is accused of. Did the judge believe that the defendant had indeed committed a criminal act or not?

A criminal judgment based on Article 183 of the Criminal Code can only be passed by a judge if there are: (i) two legal evidence and (ii) the judge obtains conviction. ${ }^{3}$ According to Pangaribuan, ${ }^{4}$ the amount of evidence found by the judge from the point of view of the concept of the Criminal Code can be called "perfect evidence" because it is a basis for confirming guilt and passing sentences. In the Criminal Code, in addition to "perfect evidence", there are also forms of "sufficient preliminary evidence" and "sufficient evidence". Sufficient preliminary evidence is equivalent to probable cause (in the literature it is a clause to make an arrest). Sufficient evidence is equivalent to "probable cause" and "reasonablesness" (in the literature it is a clause to make a containment).

After the agenda of the trial of evidence, then the next is the verdict of the court session. ${ }^{5}$ If the construction of the strong indictment includes if the evidence belonging to the defendant or a third party with good intentions is legally confiscated in relation with the corruption, the judge will decide that the evidence is confiscated for the State, the interest is to return the material loss of the State. However, if on the other hand the judge considers the evidence to be unrelated, then it must be returned or submitted to a third party as the legal owner.

Article 194 paragraph (1) of the Criminal Code states:

"In the case of a conviction or acquittal for all lawsuits, the court determines that the confiscated evidence is handed over to the party most entitled to receive back whose name is stated in the decision unless according to the provisions of the law the evidence must be confiscated for the benefit of the State or destroyed or damaged so that they can no longer be used."

If the claim against evidence is accompanied by a petitum "confiscated for the State" and the judge grants it, then the verdict must also clearly state that "evidence is confiscated for the state." A verdict that clearly states that a certain object is declared confiscated, so that the act of seizing or confiscating and executing has strong legal grounds. The importance of the inclusion of the verdict "confiscated" in a court decision that is legally binding is also intended to show that a decision to confiscate object rights has fulfilled the principle of publicity. In this way, the public can know that the status of an object has actually been "confiscated" through a court decision which has permanent legal force, hence the interested parties can (be given the opportunity) to file an objection.

As in the case of corruption which ensnared the General Chairperson of PPP Romahurmuzy (RMY) in the corruption "auction for positions" in the Ministry of Religion, On March 18, 2019, the Corruption Eradication Commission searched the office of the Minister of Religion Lukman Hakim Syaifuddin and confiscated some money. The search was related to a bribery case for a position auction that ensnared the General Chairperson of PPP Romahurmuzy. Judges of the Corruption Eradication Commission (KPK) in Central Jakarta in decision No. 8/Pid.Sus-TPK/2019/PN Jkt.Pst on Monday (20/1/2020) ordered the Corruption Eradication Commission to return

1 Marzuki, P.M. (2011). Penelitian Hukum, Jakarta: Kencana Prenada Media Group, p. 35

2 Irwansyah. (2020). Penelitian Hukum, Pilihan Metode \& Praktik Penulisan Artikel, Yogyakarta: Mirra Buana Media, p. 61-63

3 Article 183 Criminal Procedure Code states that a judge may not impose a sentence on a person unless with at least 2 (two) legal evidence he is convinced that the criminal act actually occurred and that the defendant was guilty of committing it.

4 Luhut M.P. Pangaribuan et al. (2009). Suatu Studi Teoritis Mengenai Sistem Peradilan Pidana Indonesia, Jakarta: Universitas Indonesia, p. 109

5 Alamsari, S. Heny., Irwansyah, Muhadar, Heryani, W. (2019). Law Enforcement of Money Laundering: Case Studies on Fighting Narcotic Crime, Journal of Law, Policy and Globalization, Vol. 88, 12 
the money confiscated from the work space of the former Minister of Religion Lukman Hakim Saifuddin. The panel considered that during the examination process at the trial there were no facts that stated that the money was related to the actions of the defendant (Romy).

The evidence confiscated by the Corruption Eradication Commission and ordered by the judge to be returned to the Minister of Religion are:

1. A brown envelope with the words "Greeting the Religious Instructor of the Provincial Office of the Ministry of Religion of DKI JKT" containing Rp. 70 million in 100.000 denominations (688 sheet) and 50.000 denominations (24 sheet).

2. Another brown envelope containing 300 pieces of cash worth Rp. 30 million in 100.000 denominations.

3. A brown envelope containing Rp 59.7 million in 100.000 denominations (597 sheet).

4. A brown envelope containing Rp. 30 million in 100.000 denominations (300 sheet).

5. A handbag containing US\$ 30.000 in US\$ 300 denominations

Another case is the corruption of Syarifuddin Umar (former supreme court judge). In 2012, Syarifuddin was sentenced to four years in prison and a fine of Rp 150 million, a subsidiary of four months in prison for being proven to have accepted a bribe of Rp 250 million from the curator of PT. Skycamping Indonesia (PT. SCI) Puguh Wirawan while handling a case of bankruptcy. Syarifuddin filed a pretrial and (civil) objection to the confiscation and for some of his assets confiscated by the Corruption Eradication Commission. As a result, the decision of the Supreme Court No. 2580 K/Pdt/2013 dated March 13, 2014 and a review, namely a decision No. 597 PK/Pdt/2015 dated February 24, 2016, ordered the Corruption Eradication Commission to provide compensation of Rp. 100 million to former judge Syarifuddin Umar who was sentenced to four-year imprisonment and fines in bribery cases. The Corruption Court of South Jakarta decided to oblige the South Jakarta to pay compensation of Rp. 100 million and return Rp. 2 billion belonging to the plaintiff (Syarifuddin) which the Corruption Eradication Commission had confiscated.

If the objects (items) confiscated by the Corruption Eradication Commission are deemed by the suspect to be completely unrelated to the criminal act to him, then the suspect has the right to file a pretrial action as stipulated in Articles 77 to 83 of the Criminal Code, ${ }^{1}$ and if after the court examines the subject matter, declares the defendant guilty, the Panel of Judges can also judge whether the items confiscated by the Corruption Eradication Commission are the result of the alleged corruption crime. If indeed the Panel of Judges believes and thinks so, then the confiscated assets can be declared confiscated by the State. However, if the Panel of Judges is of the opinion that the confiscated items have no relation with the criminal act charged, the Panel of Judges may order the confiscated objects to be returned to the defendant or those who are entitled.

However, there are differences in the two cases, in the case of Romahurmuzy, the Minister of Religion Lukman Hakim as a third party did not file a legal objection to his personal assets as confiscated by the Corruption Eradication Commission. Meanwhile, in the case of former judge Syarifuddin Umar, he filed a pretrial which was granted by the court.

\section{Ideal Design for Legal Protection of Third-Party Property Rights in Corruption Crime Prosecution}

There is legal protection for third parties in maintaining assets confiscated by investigators during the investigation process, as well as the right to file a pretrial and attempt to object to a judge decision if the verdict states that evidence is confiscated for the State. The guarantee of legal protection is stated in several laws and regulations such as Article $28 \mathrm{H}$ paragraph (4) of the 1945 Constitution that "Every person has the right to have private property rights and these property rights cannot be taken over arbitrarily by anyone."

Although, this legal protection has not been maximal in protecting the personal property of a defendant or a third party who has been confiscated arbitrarily even though it is not related to the corruption case being investigated or prosecuted before a court session. Legal protection has not been maximized because in practice the third party with an interest in the object of confiscation is only given the right to take legal remedies in 2 (two) ways; the first through pretrial in accordance with the decision of the Constitutional Court No. 21/PUU-XII/2014, and the second through a civil suit (objection) within 2 (two) months after the decision was read (Article 19 paragraph (2) of the Corruption Laws No. 31 of 1999).

As discussed in the previous section, that if private property rights are confiscated during the investigation stage,

1 On 28 April 2015, the Constitutional Court revised the provisions of Article 77 letter $a$ of the Criminal Procedure Code concerning pretrial objects and a number of other articles in the Criminal Procedure Code regarding sufficient preliminary evidence. The Constitutional Court considers Article 77 letter $a$ of the Criminal Procedure Code to be unconstitutional as long as it is interpreted, including the determination of the suspect, searches and confiscation. 
then a suspect or third party has the right to file a pretrial as stated in the decision of the Constitutional Court No. 21/PUU-XII/2014 on 28 April 2015 which expands the provisions of Article 77 letter $a$; the Criminal Code regarding pretrial objects and several articles in the Criminal Code concerning sufficient preliminary evidence. The Constitutional Court considers Article 77 letter $a$ of the Criminal Code to be unconstitutional as long as it is interpreted, including the determination of the suspect, searches and confiscation. The pretrial object which becomes the authority of the District Court prior to the Constitutional Court decision is only; a) whether or not the arrest, detention, termination of investigation or prosecution is legal; b) compensation and or rehabilitation for a person whose criminal case is terminated at the level of investigation or prosecution.

Filing an objection by third parties is given a grace period of 2 (two) months from the time the court verdict is pronounced at a trial open to the public. If the time limit specified by law has passed, the third party still has the right to file a civil suit to the court, and the law is within the scope of civil law, both formal and material. Protection of property rights is emphasized in Burgerlijk Wetboek (BW) as contained in article 574 which reads: "every owner of a material has the right to sue whoever controls it, to return the object in its current state".

According to author, the two ways to take legal action to defend their civil rights have not provided maximum legal protection to third parties with good intentions. Because the first, the third party has a passive status in the prosecution trial. Although he can appear as a witness, the public prosecutor or defendant must propose it. If not, then he will not have the space or opportunity to explain the origin of his civil rights which is the object of the confiscation.

The second, although a third party can use their legal right to file a pretrial against their civil rights which is the object of the confiscation, the procedural law or process is separate from the prosecution trial. The third party is not together with the parties in the same trial (prosecution session) to explain the origin of their civil rights which is the object of the confiscation. Separate pretrial and prosecutorial hearings make it difficult for third parties to explain the origin of their civil rights as objects of confiscation.

As happened in the case of a lawsuit filed by Anita, a customer of the insurance company Wanna Artha Life, whose pretrial was rejected due to the blocking of the accounts of a number of Wanna Artha Life customers, including herself. The pretrial was rejected because the main case had been examined in accordance with Article 82 paragraph 1 letter $d$ of the Criminal Code which stated that the pretrial petition was canceled when the main case had been examined.

The third, the right to file a resistance effort through a lawsuit at the latest 2 (two) months after the court decision is pronounced in an open court to the public as referred to in Article 19 paragraph (2) of Act No. 31 of 1999 on the Corruption Eradication, causing the third party to be delayed to explain his legal interests related to his civil rights which are the object of the confiscation.

The fourth, the issue of the authority to examine and adjudicate (competence). Article 19 of the Corruption Law No. 31/1999 and its elucidation does not mention the competence of the court which has the authority to examine and adjudicate the objection. What is the competence at the location/address of the object of confiscation, what is the domicile address of the accused of corruption, what is the court where the case was tried, or the domicile address of a third party? For example, when the prosecutor, the Corruption Eradication Commission or the Attorney General' Office investigated and prosecuted a corruption case that was related to money laundering, the Corruption Eradication Commission took the case to Jakarta and prosecuted it at a court hearing in Jakarta, even though the corruption case occurred in another area. This certainly brings difficulties to the third party if the third party and its assets are domiciled or located in another area, not in Jakarta.

The absence of a third party in the prosecution hearing which was only attended by the defendant and the prosecutor made the process of finding material truth about the confiscated third party objects that were lame or imperfect, because they did not present the information or testimony of the third party with the most interest in the confiscated object. This is a weakness in the practice of criminal procedural law at the prosecution court which needs to be improved in order to realize formal and material justice as the goal of criminal procedural law.

\section{Initiating a Legal Protection Model for Third Party-Owned Evidence in the Prosecution Stage}

Normatively, legal protection against confiscation of object not belonging to the defendant is not imposed if the rights of a third party in good faith will be harmed. However, legal protection is imperfect because the third party is not drawn as a related party in the prosecution trial. The prosecution hearing only involved the prosecutor and the defendant who was accompanied by their legal counsel. Whereas the third party has a legal interest to explain and prove their civil rights regarding the origin of the goods or assets which are the object of the confiscation.

This is in line with the current trend towards an adversarial system, which means that the position of public 
prosecutors and defendants and their legal advisors is balanced in court. ${ }^{1}$ For example, in the practice conducted in the common law system or Anglo-Saxon, efforts to protect third parties or other parties in the judicial process can be found through the application of the Motion in Limine concept, where in the judicial process it is possible to have an institution (a kind of pretrial institution) which allows the entry of Third Parties with good faith as parties in the case in order to defend their interests by asking the judge to exclude evidence which according to him may interfere with the legal interests for him, including evidence in the form of property belonging to the third party in good faith.

In a country with a common law or Anglo-Saxon legal system, one of which is the United States, this is known as "Motion in Limine". In the book "Terminologi Hukum Amerika,"2 Mac Aditiawarman defines Motion in Limine as: A pretrial action to ask the court to exclude the content of the presentation because it is very detrimental to one of the parties to the agreement.

This Motion in Limine is contained in the "Federal Rule Evidence (FRE)" article 403 about Excluding Relevant Evidence for Prejudice, Confusion, Waste of Time, or Other Reason, which states that:

"The court may exclude relevant evidence if its probative value is substantially outweighed by a danger of one or more of the following: unfair prejudice, confusing the issues, misleading the jury, undue delay, wasting time, or needlessly presenting cumulative evidence. ${ }^{3}$

By this provision, it is possible for the judge to issue evidence which although relevant to the subject matter of the case being tried is based on the consideration that the use of such evidence is deemed to interfere or endanger the rights and interests of other innocent parties, as well as other considerations.

In order to reform a criminal justice system, especially at prosecution sessions with an agenda of trial of evidence, a third party in good faith must be given the legal right to explain the origin of the property or asset which is the object of confiscation. This legal right is to provide more legal protection to third parties. So the third party does not need to file a pretrial, civil suit after the verdict (60 days) which has the potential to violate civil rights due to legal certainty regarding the ownership of the confiscated object is delayed.

To avoid the possibility of a third party not being presented, whether for legal or non-legal reasons, article 19 gives the third party the right to submit an application to the Head of the District Court to be presented as a third party (or in civil terms it is usually called "the parties"). The third party who feels that their legal interests are disturbed by the confiscation has the right to submit a request to the judge to be presented. If a third party has good faith, it can be in a trial process together with the defendant and the prosecutor. The judge can immediately hear the testimony and see the evidence that will be presented in front of him by the third party so that the chain of material truth regarding the object of confiscation will be open as clearly as possible, whether it originated or has something to do with the criminal act of corruption that was charged against the defendant, or not, in the sense that it belongs to a legal third party.

However, this provision is optional. Third parties are given the choice to exercise their legal rights. If not, then there will be no legal right for him to defend his civil rights interests over the confiscated property. There is no pretrial, there is no remedy for objection after the decision is legally binding. However, if a third party uses that legal right, it can be beneficial, it could also harm him. This is beneficial because he will be in the same trial as the defendant and the prosecutor. His testimony was seen directly before the judge. He can immediately verify the origin of the confiscated object, whether or not it has anything to do with the corruption case being tried.

In that process, the third party will be subject to reverse proof or reversal burden of proof. From the language side it is known as "Omkering van het Bewijslast" or "Reversal Burden of Proof". ${ }^{4}$ Conversely, if the third party cannot prove the origin of the confiscated object, then the judge will issue a determination of a suspect for the third party because he has committed lies before a glorified trial, the trial is a sacred process in which the third party' testimony is heard under oath.

Through the reform of the criminal procedure law at this prosecution trial, third parties are also subject to reversal burden of proof. Hence, this provision can provide benefits to the practice of criminal procedural law, particularly at prosecution sessions. The first, cut time. The presence of a third party in the prosecution trial can cut time in providing legal certainty regarding the legal status of the object claimed by the third party which is the object of confiscation. This provision eliminates pretrial and counterclaims (civil/derden verzet) against the confiscation of objects of confiscation. The legal status of the object of confiscation that was claimed by a third party was

1 Academic Paper of the Draft Law on the Criminal Procedure Code, p. 20

2 Mac Aditiawarman, Terminologi Hukum Amerika, (Padang: Ekasati University Press, 2011), p.101

$3 \mathrm{https} / / /$ www.law.cornell.edu/rules/fre/rule_403, accessed on Sunday 19 July 2020 at 17:16 p.m.

4 Akil Mochtar, Pembalikan Beban Pembuktian Tindak Pidana Korupsi, loc.cit., p. 129 
completed in one trial, the prosecution trial. If the defendant or a third party does not accept the decision, they can use their rights for further legal remedies, appeal, cassation and review, in one case number.

The second, efficiency in case handling. The separation of the judicial process on the confiscated goods/objects in the corruption case as described on the previous page (pretrial and civil suit/resistance) has delayed legal certainty of the confiscated object. Due to the separate trial process, even though what is trying to prove is the object which is also the evidence in the corruption court trial, so it becomes inefficient in terms of the case handling process.

The third, avoiding disparity in decisions. Separating the evidentiary process in the corruption court with the pretrial and civil proceedings (resistance from third parties or defendants) can result in disparities in decisions that confuse justice seekers. There may be disparities in decisions between pretrial, civil suit (resistance) and verdicts in corruption cases. This situation also has an impact on delayed legal certainty because the parties can take further legal remedies. The fourth, avoiding the practice of corruption. The process of proving the object of confiscation in a prosecution agenda minimizes the opportunity for corruption (bribery). This does not mean that the one-stop prosecution trial does not have the potential for corruption, but the unification of the proving trial process in one prosecution trial will reduce the corruption space compared to being separated. The monitoring performance of related supervisory agencies such as the prosecutor' commission, judicial commission, police commission and civil society anti-corruption activists can also focus more on the prosecution trial.

\section{Conclusion}

To provide legal protection to the confiscation object of third party which becomes evidence in the prosecution, it is important that a third party be present at the prosecution hearing. Through the prosecutor who asked the panel of judges to withdraw the third party as parties to explain the origin of the material rights which were the object of the confiscation. Updating this provision will provide benefits: the first is time efficiency. The presence of a third party in the prosecution trial can cut time in providing legal certainty regarding the legal status of the object claimed by the third party which is the object of confiscation. This provision eliminates pretrial attempts and challenges (civil/derden verstek) against the confiscation of objects of confiscation. The legal status of the object of confiscation which is claimed by a third party is completed in one trial, the prosecution trial; the second is efficiency of case handling for proving the validity of the object of confiscation of evidence belonging to a third party occurs in just one prosecution hearing, there is no pretrial effort and resistance to objections after the decision. The third is avoid disparity in decisions. Separating the evidentiary process in the corruption court with the pretrial and civil proceedings (resistance from third parties or defendants) can result in disparities in decisions that confuse justice seekers. The fourth is avoid the practice of corruption. The process of proving the object of confiscation in one agenda of the prosecution session minimizes the chance of corruption (bribery) because the evidence trial focuses on the prosecution trial only.

\section{References}

Alhumami, K., Arie, M., Musakkir, Sampurno, S.S. (2020). Attorney's Independence in Implementing Law Enforcement Duties: Challenges and Development, Journal of Law, Policy, and Globalization, Vol. 95, $106-112$

Andi Hamzah, "Posisi Kejaksaan dalam Sistem Ketatanegaraan RI", National Symposium "Hari Bhakti Adhyaksa". Held by Pusat Litbang Kejaksaan Agung. Jakarta: 20 July 2000.

Garner, B.A. (2009). Black's Law Dictionary, ST. Paul: West Group.

Hellmann, O. L. L. I. (2015). "The Institutionalisation of Corruption: The Neglected Role of Power." In th PSA Annual International Conference Sheffield, vol. 30. 12-43.

Hussein, Y. (2007). Bunga Rampai Anti Pencucian Uang, Bandung: Books Terrace \& Library.

Hussein, Y. (2008). Negeri Sang Pencuci Uang, Jakarta, Pustaka Juanda Tigalima.

Irwansyah. (2020). Penelitian Hukum, Pilihan Metode \& Praktik Penulisan Artikel, Yogyakarta: Mirra Buana Media.

Lamintang, (1984). KUHAP dengan Pembahasan secara Yuridis menuruf Jurisprudensi dan ilmu Pengetahuan Hukum Pidana, Bandung: Sinar Baru.

Lewis-Faupel, S., Neggers, Y., Olken, B. A., \& Pande, R. (2016). Can electronic procurement improve infrastructure provision? Evidence from public works in India and Indonesia. American Economic Journal: Economic Policy, 8(3), 258-83.

Luhut M.P. Pangaribuan et al. (2009). Suatu Studi Teoritis Mengenai Sistem Peradilan Pidana Indonesia, Jakarta: 
Universitas Indonesia.

Mac Aditiawarman, (2011). Terminologi Hukum Amerika, Padang: Ekasati University Press.

Marzuki, P.M. (2011). Penelitian Hukum, Jakarta: Kencana Prenada Media Group.

Mochtar, A. (2009). Pembalikan Beban Pembuktian Tindak Pidana Korupsi. Jakarta: Serketariat Jenderal dan Kepaniteraan Mahkamah Konstitusi.

Njoto-Feillard, G., \& Azali, K. (2016). Is a New Entrepreneurial Generation Emerging in Indonesia?. SEAS Yusof Ishak Institute. http://hdl.handle.net/11540/9160.

Schütte, S. A. (2012). Against the odds: Anti-corruption reform in Indonesia. Journal Public Administration and Development, 32(1), 38-48.

Semma, M. (2008). Negara dan Korupsi; Pemikiran Mochtar Lubis Atas Negara, Manusia Indonesia dan Perilaku Politik, Jakarta: Yayasan Obor Indonesia.

Setyaningrum, D., Wardhani, R., \& Syakhroza, A. (2017). Good public governance, corruption and public service quality: Indonesia evidence. International Journal of Applied Business and Economic Research, 15(19), 327-338. 